
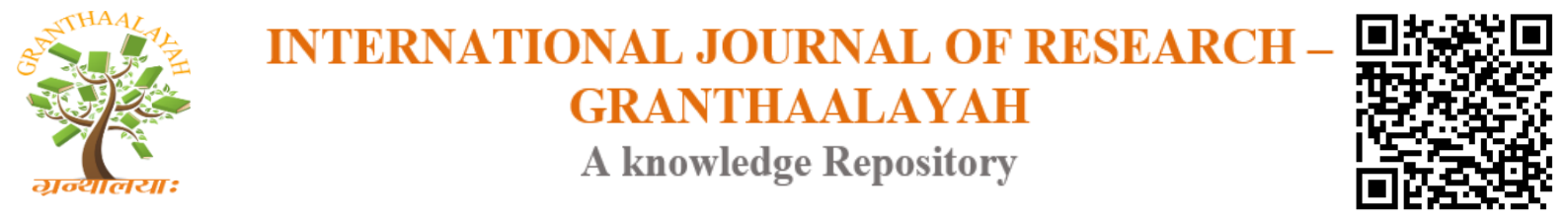

Management

\title{
ECONOMICS OF SMALL ONION IS IT FEASIBLE TO THE PRODUCERS? - A CASE STUDY
}

\author{
Dr. Rajendran, $\mathbf{T}^{* 1}$ \\ Assistant Professor [Agrl. Economics], Tamil Nadu Agricultural University [TNAU], \\ Agricultural College and Research Institute, Eachnagkottai, Thanjavur - 614 902, India
}

DOI: https://doi.org/10.29121/granthaalayah.v5.i2.2017.1713

\begin{abstract}
While the farming community is facing a heavy loss in the cultivation of crops such as paddy, sugarcane and turmeric, vegetables, particularly the small onions, give them a significant return. The income from the vegetables helps the farmers to meet their living expenses. This study is purposefully conducted as termed as Case Study in Thiru. Duraimurugan, [Mobile No: 078454 16243] farmer in Village of Kanmaniyapuram, Kadayanallur Taluk, Tirunelveli District. The case study revealed that, the benefit-cost ratio is 1:1.4 that means, if the farmer will spend one rupee the profit is rupee 1.4. In fact, that the farmer has been really struggling with the BreakEven Point. They face huge loss owing to poor yield. He must modify their production pattern and verify each cost component, which component to be minimize and which inputs might add to get higher profit with lower cost production.
\end{abstract}

Keywords: Case Study; Small Onion; Benefit-Cost Ratio; Economics; Agricultural Marketing.

Cite This Article: Dr. Rajendran, T. (2017). "ECONOMICS OF SMALL ONION IS IT FEASIBLE TO THE PRODUCERS? - A CASE STUDY." International Journal of Research - Granthaalayah, 5(2), 135-138. https://doi.org/10.29121/granthaalayah.v5.i2.2017.1713

\section{Introduction}

The small onion prices may be bringing tears to the consumers. But the farmers who are engaged in the cultivation of the crop in the Tirunelveli district are making a handsome profit this year as the prices have shot up to Rs. 40 to Rs. 45 a $\mathrm{kg}$, Small onion is a short-term crop. Its water requirement is modest when compared to paddy and sugarcane. Since cash crops like turmeric do not fetch good income. The return is good because the price remains high in the market, says Thiru. Duraimurugan [Mobile No: 078454 16243] farmer in Village of Kanmaniyapuram, Kadayanallur Taluk, Tirunelveli District, who cultivated small onions in an acre of his land. It is also important to conduct an economic analysis of small onion as way of Case Study, which will help to improve the productivity of the farmers through appropriate policy interventions. 


\section{Objectives}

Major objective of the study is to assess the economic analysis of small onion. In the very famous tool of Case Study, The specific objectives were:

i. To assess the economics of small onion; and

ii. To suggest the policy measures to improve productivity of small onion farmers.

\section{Methodology}

Let us see what's happening in the actual situation in the field of economic cultivation for Small onion. The actual practices are done [Case Study] by Thiru. Duraimurugan, [Mobile No: 078454 16243] from Kanmaniyapuram, Kadayanallur Taluk, District of Tirunelveli.

\section{Period of Study}

The study was conducted during October, 2016

\section{Limitations of the Study}

The study is primarily based on the field level data collected through interviews and discussion with the farmers. Hence, the usual limitations resulting from the recall bias of the farmers apply to this study as well, further, this study was done in a specific agro-climatic region covering specific time and hence the results should be carefully interpreted.

\section{Results and Discussions}

The following costs of operations in small onion were gathered and discussed very consciously. Let us see the actual cost of cultivation of small onion and make an attempt which factors of production is to be give more profit with maximization of productivity,

\section{Table 1: Economics of Small of Onion [acre]}

\begin{tabular}{|c|c|c|c|}
\hline $\begin{array}{l}\text { S. } \\
\text { No }\end{array}$ & Operations & $\begin{array}{l}\text { Quantity [kg/lit/ } \\
\text { Number/Hours] }\end{array}$ & Value [Rs] \\
\hline 1 & $\begin{array}{cl}\text { i. } & \text { Main field preparation Tractor } \\
\text { ii. } & \text { Ridges and furrows JCP }\end{array}$ & $\begin{array}{l}3 \\
3 \\
\end{array}$ & $\begin{array}{l}3600 \\
4200\end{array}$ \\
\hline 2 & $\begin{array}{l}\text { Seed rate [bulbs] } \\
\text { Rs. } 22 / \mathrm{kg}\end{array}$ & 400 & 8800 \\
\hline 3 & $\begin{array}{l}\text { Sowing and Planting } \\
\text { Rs. 150/female labour }\end{array}$ & 18 & 2700 \\
\hline 4 & Irrigation & 3 & 450 \\
\hline 5 & $\begin{array}{l}\text { Manures and Fertilizers } \\
\text { First time } \\
\text { i. Basal application - DAP } \\
\text { ii. N: P: K } \\
\text { Second time }\end{array}$ & $\begin{array}{l}150 \\
60: 45: 30\end{array}$ & $\begin{array}{l}3150 \\
1800\end{array}$ \\
\hline
\end{tabular}




\begin{tabular}{|c|c|c|c|}
\hline & $\mathrm{N}: \mathrm{P}: \mathrm{K}$ & $30: 60: 45$ & 2250 \\
\hline 6 & $\begin{array}{l}\text { Weeding } \\
\text { First time } \\
\text { Second time }\end{array}$ & $\begin{array}{l}12 \\
18\end{array}$ & $\begin{array}{l}1800 \\
2700\end{array}$ \\
\hline 7 & $\begin{array}{l}\text { Plant protection } \\
\text { i. Fertilizers } \\
\text { Ammonium Sulphate:P:K } \\
\text { ii. Thrips }\end{array}$ & $\begin{array}{l}\text { 60:15:15 } \\
3\end{array}$ & $\begin{array}{l}3000 \\
6000\end{array}$ \\
\hline 8 & Harvesting & 75 & 11250 \\
\hline 9 & $\begin{array}{l}\text { Transport } \\
\text { Truck }\end{array}$ & 3 & 450 \\
\hline 10 & \begin{tabular}{|l|} 
Market Commission charge \\
Total Cost
\end{tabular} & & $\begin{array}{l}550 \\
52700 \\
\end{array}$ \\
\hline 11 & $\begin{array}{l}\text { Profit } \\
\text { Rs. 10/kg }\end{array}$ & 6000 & 60000 \\
\hline & Benefit-Cost Ratio & & 1:1.4 \\
\hline
\end{tabular}

The above Table 1, will shows that the benefit-cost ratio is 1:1.4 that means, if the farmer will spend one rupee the profit is rupee 1.4. Have you aware that what is the implication? Yes. The farmer has been really struggling with the Break-Even Point. They face huge loss owing to poor yield.

He must modify their production pattern and verify each cost component, which component to be minimize and which inputs might add to get higher profit with lower cost production.

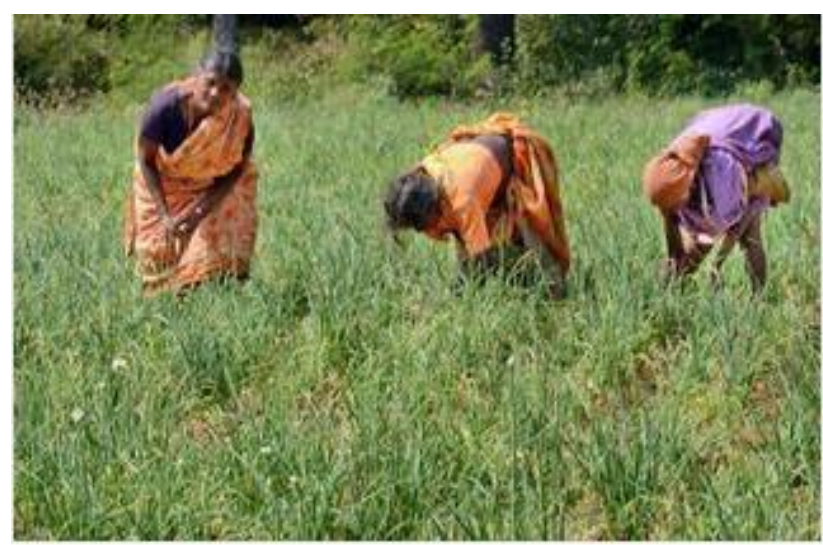

a) Women working at an onion field near Kadayanallur Taluk

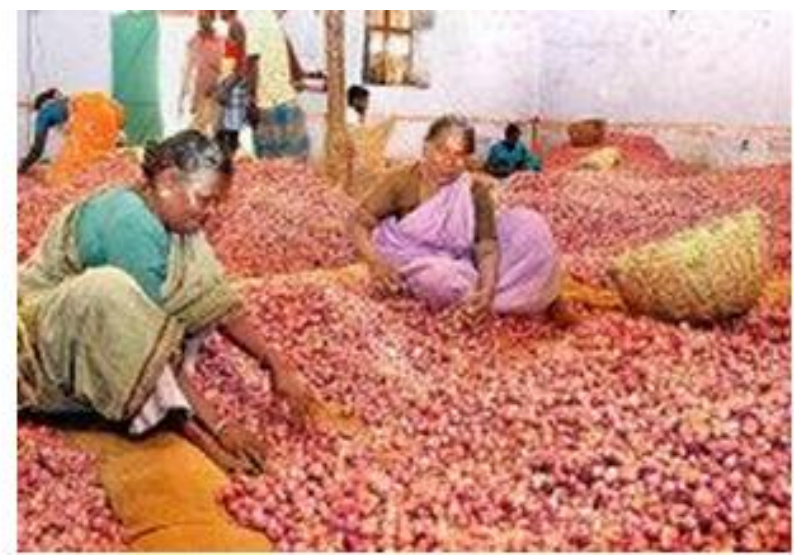

b) Small Onion Farmers are processing

\section{Suggestions}

- Normally rain brings cheers to farmers. But it does not shower blessings on small onion growers who face huge loss this season, owing to poor yield. Incessant rain in Novemberend did the maximum damage to standing onion crops on thousands of hectares in the district. Fog since mid-December too harmed the crop further. 
- Onion growers feel the burden only when they attempted to harvest. Now, they harvest only 50 per cent of total yield they got in last season.

- Sharp slump in yield resulted in steep hike in prices of onion in whole sale market. But such price hike does not benefit them as it fails to meet their initial costs even.

- Most of the farmers in India sell their produce through village level markets, fairs, Mandies, Co-operative Societies, and directly through intermediaries like agents etc.

- In the above process of agricultural marketing, there may be possibility of middlemen exploit farmers as well as consumers. Consequently, farmers has not get fair price and even not able to meet the cost of cultivation results in indebtedness.

- To eliminate the middlemen between farmers and consumers, government level intervention worked out by the policy makers in different state introduces the farmer market concept as an alternate to agricultural marketing. It is being known by different names like Uhavar santhai, buy-back segment, direct marketing etc.

\section{Acknowledgement}

The author is highly acknowledged to Th. V. Ramesh., Diploma [Agri.] who has been more help during the field data collection.

\section{References}

[1] Farm survey, 2016.

[2] Horticultural Crop Production Guide, 2013.

*Corresponding author.

E-mail address: rajendran.t@tnau.ac.in 